\title{
Vaginal candidosis: relation between yeast counts and symptoms and clinical signs in non-pregnant women
}

\author{
V HOPWOOD, ${ }^{*}$ T CROWLEY, $\dagger$ C T HORROCKS, $\dagger$ J D MILNE, $\uparrow$ P K TAYLOR, $\dagger$ \\ D W WARNOCK*
}

From the Departments of *Microbiology and $\dagger$ Genitourinary Medicine, Royal Infirmary, Bristol

SUMMARY Of 277 non-pregnant women, $67(24 \%)$ harboured Candida albicans in the genital tract. Of 56 women yielding $C$ albicans who had no other infection diagnosed, 14 were symptomless and 10 had no clinical signs of vulval redness, vaginitis, or discharge. Symptoms and signs tended to be more severe in women with higher yeast counts. Of 22 women with moderate or severe symptoms (pruritus with or without discharge) and signs, 15 had yeast counts of more than $10^{3}$ colony forming units (cfu) $/ \mathrm{ml}$, whereas six of nine women with no symptoms or signs had counts of fewer than $10^{3} \mathrm{cfu} / \mathrm{ml}$.

Candida albicans is a common commensal of man and can be recovered from the mouth and intestinal tract of a substantial proportion of healthy people. It is still not clear, however, to what extent this yeast can be regarded as a normal inhabitant of the lower genital tract of women. Although symptomless vaginal colonisation can occur in non-pregnant women, ${ }^{12}$ and can persist for a long time, ${ }^{3}$ women harbouring $C$ albicans in the genital tract often complain of pruritus with or without vaginal discharge. ${ }^{124}$ Even if these symptoms are absent, clinical examination will often show signs of vaginitis or vulvitis. ${ }^{4}$

Although the host factors that might permit symptomless vaginal colonisation with $C$ albicans to progress to symptomatic infection have been the subject of numerous investigations, whether the amount of yeast present in the lower genital tract affects symptoms and clinical signs has seldom been studied. This investigation was designed to assess whether there is any relation between yeast counts in vaginal washings and the presence and severity of particular symptoms and clinical signs typical of vaginal candidosis in non-pregnant women.

\section{Patients and methods}

PATIENTS

For this investigation we selected at random nonpregnant women attending the genitourinary medicine clinic of the Bristol Royal Infirmary or family planning clinics at two health centres in Bristol. Each

\footnotetext{
Address for reprints: Dr V Hopwood, Department of Microbiology, Bristol Royal Infirmary, Bristol BS2 8HW

Accepted for publication 20 April 1988
}

woman was asked to grade symptoms of vulval soreness, vulval pruritus, and vaginal discharge as being absent, mild, moderate, or severe. We then examined the women and graded on a similar scale clinical signs of vulval redness, vaginitis (if any part of the vaginal mucosa was reddened or granular), and vaginal discharge.

\section{COLLECTION OF SPECIMENS}

A high vaginal swab for yeast culture was taken and placed in trichomonas medium No 2 (Oxoid Limited, Basingstoke, England). Further vaginal, cervical, and urethral swabs were taken to exclude bacterial vaginosis and infection by Trichomonas vaginalis, Neisseria gonorrhoeae, or Chlamydia trachomatis. We then instilled $10 \mathrm{ml}$ sterile distilled water into the posterior fornix and counted yeast cells in the washings. We recovered about $8 \mathrm{ml}$ of washings from each patient. All swabs and vaginal washings were stored at $4^{\circ} \mathrm{C}$ in the clinic until collected for mycological investigation. Specimens were processed one to two hours after being taken.

\section{PROCESSING OF SPECIMENS}

The swab in transport medium was used to inoculate a plate of Sabouraud's dextrose agar (SDA) (containing $0.05 \mathrm{mg} / \mathrm{ml}$ chloramphenicol). The swab was then replaced in the transport medium and, together with the plate, incubated at $37^{\circ} \mathrm{C}$ for 48 hours. The plates were examined and growth recorded as being fewer than 10,10 to 200 , or more than 200 colonies. If no growth had occurred, the swab in transport medium was used to inoculate a fresh SDA plate which was incubated at $37^{\circ} \mathrm{C}$ for 48 hours.

Tenfold serial dilutions of the vaginal washings were 
prepared in sterile water, and $0.1 \mathrm{ml}$ of each dilution was then spread on to SDA plates. The plates were dried and incubated at $37^{\circ} \mathrm{C}$ for 48 hours. We counted the number of colonies and estimated the number of colony forming units (cfu) per ml of undiluted washings.

Isolates were identified as $C$ albicans on the basis of germ tube production in horse serum after incubation at $37^{\circ} \mathrm{C}$ for 3 hours. Germ tube negative isolates were identified further with the API 20C AUX yeast identification system (API Laboratory Products, Basingstoke, England).

\section{Results}

Of the 277 women selected for this investigation, 67 yielded $C$ albicans from the lower genital tract. Five harboured other yeasts ( $C$ glabrata $(2), C$ guilliermondii (1), C parapsilosis (1), and Saccharomyces cerevisiae (1)). Eleven of the 67 women harbouring $C$ albicans had at least one other condition diagnosed. Of the 205 women not harbouring yeasts in the lower genital tract, 145 had no infection diagnosed and 60 had at least one other infection.

Table 1 shows the relation between vaginal yeast counts in the 67 women harbouring $C$ albicans and the presence and severity of symptoms of vulval soreness, vulval pruritus, and vaginal discharge. For comparison, details of the 145 women with no infection diagnosed were included in this table. The proportion of women complaining of moderate or severe symptoms increased as counts increased. Few women with counts of $<10^{1} \mathrm{cfu} / \mathrm{ml}$ complained of vulval soreness or pruritus, two symptoms typical of vaginal can-

Table 1 Relation between vaginal yeast counts and presence and severity of vulval and vaginal symptoms in 67 women harbouring $C$ albicans. (Figures in parentheses indicate numbers of women with another infectious condition.) Details of 145 women with no diagnosed genital infection included for comparison

\begin{tabular}{|c|c|c|c|c|c|}
\hline \multirow[b]{2}{*}{ Symptom and grade } & \multicolumn{4}{|c|}{ No of women with counts (cfu/ml) of: } & \multirow[b]{2}{*}{ No of uninfected women } \\
\hline & $<10^{\prime}$ & $10^{2}-10^{2}$ & $10^{3}-10^{5}$ & $>10^{5}$ & \\
\hline $\begin{array}{l}\text { Vulval soreness: } \\
\text { Absent } \\
\text { Mild } \\
\text { Moderate } \\
\text { Severe }\end{array}$ & $\begin{array}{l}9(2) \\
3 \\
0 \\
0\end{array}$ & $\begin{array}{r}11(2) \\
5(1) \\
5(1) \\
2\end{array}$ & $\begin{array}{l}11(3) \\
7(1) \\
6 \\
4(1)\end{array}$ & $\begin{array}{l}0 \\
1 \\
2 \\
1\end{array}$ & $\begin{array}{r}113 \\
16 \\
15 \\
1\end{array}$ \\
\hline $\begin{array}{l}\text { Vulval pruritus: } \\
\text { Absent } \\
\text { Mild } \\
\text { Moderate } \\
\text { Severe }\end{array}$ & $\begin{array}{l}9(2) \\
2 \\
1 \\
0\end{array}$ & $\begin{array}{l}8(2) \\
7(1) \\
6(1) \\
2\end{array}$ & $\begin{array}{l}8(1) \\
9(2) \\
8(2) \\
3\end{array}$ & $\begin{array}{l}1 \\
2 \\
0 \\
1\end{array}$ & $\begin{array}{r}119 \\
14 \\
7 \\
5\end{array}$ \\
\hline $\begin{array}{l}\text { Vaginal discharge: } \\
\text { Absent } \\
\text { Mild } \\
\text { Moderate } \\
\text { Severe }\end{array}$ & $\begin{array}{c}10(2) \\
1 \\
1 \\
0\end{array}$ & $\begin{array}{l}5 \\
9(2) \\
6(1) \\
3(1)\end{array}$ & $\begin{array}{l}11(2) \\
6(2) \\
8 \\
3(1)\end{array}$ & $\begin{array}{l}0 \\
1 \\
2 \\
1\end{array}$ & $\begin{array}{l}90 \\
29 \\
12 \\
14\end{array}$ \\
\hline
\end{tabular}

Table 2 Relation between vaginal yeast counts and presence and severity of vulval and vaginal signs in 67 women harbouring $C$ albicans. (Figures in parentheses indicate numbers of women with another infectious condition.) Details of 145 women with no diagnosed genital infection included for comparison

\begin{tabular}{|c|c|c|c|c|c|}
\hline \multirow[b]{2}{*}{ Sign and grade } & \multicolumn{4}{|c|}{ No of women with counts (cfu/ml) of: } & \multirow[b]{2}{*}{ No of uninfected women } \\
\hline & $<10^{\prime}$ & $10^{1}-10^{2}$ & $10^{3}-10^{5}$ & $>10^{5}$ & \\
\hline $\begin{array}{l}\text { Vulval redness: } \\
\text { Absent } \\
\text { Mild } \\
\text { Moderate } \\
\text { Severe }\end{array}$ & $\begin{array}{l}9(2) \\
3 \\
0 \\
0\end{array}$ & $\begin{array}{l}9(1) \\
8(2) \\
4(1) \\
2\end{array}$ & $\begin{array}{l}10(2) \\
7(2) \\
5 \\
6(1)\end{array}$ & $\begin{array}{l}0 \\
0 \\
2 \\
2\end{array}$ & $\begin{array}{r}110 \\
22 \\
9 \\
4\end{array}$ \\
\hline $\begin{array}{l}\text { Vaginitis: } \\
\text { Absent } \\
\text { Mild } \\
\text { Moderate } \\
\text { Severe }\end{array}$ & $\begin{array}{l}11(2) \\
1 \\
0 \\
0\end{array}$ & $\begin{array}{l}15(2) \\
7(2) \\
1 \\
0\end{array}$ & $\begin{array}{l}13(3) \\
10 \\
1(1) \\
4(1)\end{array}$ & $\begin{array}{l}0 \\
0 \\
4 \\
0\end{array}$ & $\begin{array}{r}134 \\
7 \\
4 \\
0\end{array}$ \\
\hline $\begin{array}{l}\text { Vaginal discharge } \\
\text { Absent } \\
\text { Mild } \\
\text { Moderate } \\
\text { Severe }\end{array}$ & $\begin{array}{l}7(2) \\
5 \\
0 \\
0\end{array}$ & $\begin{array}{l}2 \\
12(2) \\
4 \\
5(2)\end{array}$ & $\begin{array}{l}5 \\
12(2) \\
6(1) \\
5(2)\end{array}$ & $\begin{array}{l}0 \\
0 \\
0 \\
4\end{array}$ & $\begin{array}{r}55 \\
58 \\
24 \\
8\end{array}$ \\
\hline
\end{tabular}


Table 3 Incidence of different combinations of grades of vulval and vaginal symptoms and signs in 56 women harbouring $C$ albicans only. (Figures in parentheses indicate mumbers of women if vaginal discharge in excluded.) Details of 145 women with no diagnosed genital infection included for comparison

\begin{tabular}{|c|c|c|c|c|c|c|}
\hline \multirow{2}{*}{$\begin{array}{l}\text { Highest symptom } \\
\text { grade }\end{array}$} & \multirow{2}{*}{$\begin{array}{l}\text { Highest sign } \\
\text { grade }\end{array}$} & \multicolumn{4}{|c|}{ No of women with counts (cfu/ml) of: } & \multirow{2}{*}{$\begin{array}{l}\text { No of uninfected } \\
\text { women }\end{array}$} \\
\hline & & $<10^{\prime}$ & $10^{\prime}-10^{2}$ & $10^{3}-10^{5}$ & $>10^{5}$ & \\
\hline $\begin{array}{l}\text { Moderate or severe } \\
\text { Moderate or severe } \\
\text { Moderate or severe } \\
\text { Mild } \\
\text { Absent } \\
\text { Mild } \\
\text { Mild } \\
\text { Absent } \\
\text { Absent }\end{array}$ & $\begin{array}{l}\text { Moderate or severe } \\
\text { Mild } \\
\text { Absent } \\
\text { Moderate or severe } \\
\text { Moderate or severe } \\
\text { Mild } \\
\text { Absent } \\
\text { Mild } \\
\text { Absent }\end{array}$ & $\begin{array}{l}0 \\
1 \\
0 \\
0 \\
0 \\
2 \\
0 \\
2 \\
5\end{array}$ & $\begin{array}{l}7 \\
4 \\
0 \\
1 \\
0 \\
5 \\
0 \\
1 \\
1\end{array}$ & $\begin{array}{r}11 \\
3 \\
0 \\
1 \\
0 \\
2 \\
1 \\
2 \\
3\end{array}$ & $\begin{array}{l}4 \\
0 \\
0 \\
0 \\
0 \\
0 \\
0 \\
0 \\
0\end{array}$ & $\begin{array}{l}24(10) \\
10(5) \\
5(5) \\
8(0) \\
10(3) \\
17(8) \\
6(10) \\
29(9) \\
36(95)\end{array}$ \\
\hline
\end{tabular}

didosis. On the other hand, three of the four women with counts of $>10^{5} \mathrm{cfu} / \mathrm{ml}$ complained of moderate or severe vulval soreness. Vaginal discharge proved to be a less specific symptom and was described as moderate or severe by 26 of the 145 women with no diagnosed genital infection.

Table 2 shows the relation between vaginal yeast counts in the 67 women harbouring $C$ albicans and the presence and severity of clinical signs of vulval redness, vaginitis, and vaginal discharge. As with symptoms, the proportion of women with moderate or severe clinical signs increased as counts increased. Moderate or severe vulval redness or vaginitis was uncommon in women with yeast counts of $<10^{3} \mathrm{cfu} /$ $\mathrm{ml}$. In contrast all four women with counts of $>10^{5}$ $\mathrm{cfu} / \mathrm{ml}$ had moderate or severe vulval redness, moderate vaginitis, and severe vaginal discharge. Again, however, when considered as a clinical sign rather than as a symptom, vaginal discharge was not specific and was graded as moderate or severe in 32 of the 145 women with no diagnosed infection.

The two women harbouring $C$ glabrata had counts of $2 \times 10^{3}$ and $>1 \times 10^{5} \mathrm{cfu} / \mathrm{ml}$. The first had no symptoms or signs apart from a mild vaginal discharge, whereas the second complained of moderate vulval soreness and pruritus and was clinically graded

Table 4 Relation between yeast counts in vaginal washings and numbers of colonies grown on culture from 72 women harbouring yeasts in the vagina

\begin{tabular}{lllll}
\hline \multirow{2}{*}{$\begin{array}{l}\text { Yeast count } \\
\text { (cfu/ml) }\end{array}$} & $\begin{array}{l}\text { No of } \\
\text { women }\end{array}$ & \multicolumn{3}{l}{ No with colony Nos of: } \\
\cline { 4 - 6 } \cline { 4 - 5 } & 2 & 2 & $10-200$ & $>200$ \\
\hline $10^{1}$ & 9 & 9 & 0 & 0 \\
$10^{1}-10^{3}$ & 25 & 4 & 0 & 0 \\
$10^{3}-10^{5}$ & $23 \dagger$ & 1 & 19 & 2 \\
$>10^{5}$ & 5 & 0 & 9 & 13 \\
\hline
\end{tabular}

* Two women were positive by enrichment culture only, yeast counts were not performed.

$\dagger$ No culture results available for six women with counts of $10^{3}-10^{5}$ $\mathrm{cfu} / \mathrm{ml}$. as having moderate vulval redness and vaginal discharge. The woman harbouring $C$ parapsilosis had a count of $<10 \mathrm{cfu} / \mathrm{ml}$ and had neither symptoms nor signs. The woman harbouring $C$ guilliermondii had a count of $60 \mathrm{cfu} / \mathrm{ml}$; she had no clinical signs, but complained of severe vulval soreness and pruritus. The woman harbouring $S$ cerevisiae had a count of $500 \mathrm{cfu} /$ $\mathrm{ml}$ and complained of mild vulval soreness and pruritus, but had no clinical signs apart from a mild vaginal discharge.

Table 3 shows the vaginal $C$ albicans counts in women with particular combinations of grades of symptoms and clinical signs. The most severe grade for any one of the three different symptoms noted and any one of the three different signs assessed was used to assign each woman to a particular group. Details of the 145 women with no diagnosed infection were included for comparison. The 11 women harbouring $C$ albicans who had another infection diagnosed were excluded from this table.

Of the remaining 56 women with $C$ albicans alone, 14 were symptomless, 10 had no clinical signs of vulval redness, vaginitis, or vaginal discharge (table 3 ), and nine had neither symptoms nor signs. On the other hand, 30 had at least one moderate or severe symptom, 24 had at least one moderate or severe clinical sign, and 22 had moderate or severe symptoms and signs.

Of the 27 women with vaginal $C$ albicans counts of $\geqslant 10^{3} \mathrm{cfu} / \mathrm{ml}, 18 \mathrm{had}$ at least one moderate or severe symptom, 16 had at least one moderate or severe sign, and 15 had moderate or severe symptoms and signs (table 3). In contrast, of the 29 women with counts of $<10^{3} \mathrm{cfu} / \mathrm{ml}, 17 \mathrm{had}$ no or mild symptoms, 21 had no or mild signs, and six had neither symptoms nor signs.

Fifteen of the 22 women with moderate or severe symptoms and signs had vaginal $C$ albicans counts of $\geqslant 10^{3} \mathrm{cfu} / \mathrm{ml}$, whereas six of the nine women with no symptoms or signs had counts of $<10^{3} \mathrm{cfu} / \mathrm{ml}$ (table 3). Nineteen of the 32 women with moderate or severe symptoms or signs had counts of $\geqslant 10^{3} \mathrm{cfu} / \mathrm{ml}$, whereas 16 of the 24 women with no or mild symptoms 
or signs had counts of $<10^{3} \mathrm{cfu} / \mathrm{ml}$.

Of the 145 women with no infection diagnosed (table 3), no fewer than 39 had at least one moderate or severe symptom and 42 had at least one moderate or severe clinical sign. If vaginal discharge is ignored, however, the number with moderate or severe symptoms was 20 and the number with moderate or severe signs was 13. The number of women with no symptoms or signs increased from 36 to 95 if vaginal discharge is excluded.

Table 4 shows that yeast counts in vaginal washings correlated well with the numbers of colonies grown on culture of high vaginal swabs.

\section{Discussion}

Our findings indicate that some non-pregnant women harbouring $C$ albicans in the lower genital tract are symptomless whereas others complain of intense vulval and vaginal pruritus, with or without discharge, and have signs of vulval redness or vaginitis. A much smaller proportion of similar women harbouring no identifiable pathogen complained of similar symptoms or had identical clinical signs.

The reasons that some women harbouring $C$ albicans develop symptoms and clinical signs of infection and others do not are not well understood, but one factor that might be important is the amount of yeast present in the lower genital tract. Several investigations in which semi-quantitative culture methods were used suggested that the more yeast recovered, the more likely was the women to have symptoms and signs typical of vaginal candidosis. ${ }^{56}$ Our results confirm this association and furthermore suggest that the severity of symptoms of vulval soreness or pruritus and of signs of vulval redness or vaginitis is also related to the amount of $C$ albicans recovered from the lower genital tract. Two thirds of the women with no symptoms or signs, or no more than mild symptoms or signs, had counts of $<10^{3} \mathrm{cfu} / \mathrm{ml}$ whereas more than half $(19 / 32)$ the women with moderate or severe symptoms or signs had counts of $\geqslant 10^{3} \mathrm{cfu} / \mathrm{ml}$ (table 3 ). It would be interesting to obtain sequential specimens from symptomless women harbouring small numbers of yeasts in the genital tract to ascertain whether rising counts lead to the development of particular symptoms or signs of infection.

Although $C$ albicans has been implicated in $80-95 \%$ of cases of vaginal candidosis in non-pregnant women, other yeasts are sometimes implicated. ${ }^{12}$ Oriel et al recovered $C$ glabrata from no fewer than $16 \%$ of their patients, but more than half of that group were symptomless and most had no signs of vaginitis or vulvitis.' Our findings suggest that genital infections with yeasts other than $C$ albicans are apt to be mild and seldom associated with florid clinical signs. Investigation of a much larger number of women, however, will be required to confirm this suggestion.

Most patients who present with symptomatic vaginal candidosis have occasional infrequent episodes of this condition. Some women, however, develop chronic symptoms that do not respond well to topical medication and that recur soon after cessation of antifungal treatment. Intermittent prophylactic treatment with antifungal drugs has been shown to produce prolonged symptomatic relief in women with recurrent candidosis, even though it often fails to prevent recolonisation of the genital tract with $C$ albicans. ${ }^{7-9}$ This might be because the yeast population is maintained at a level below a threshold needed for development of symptoms and signs. It would be interesting to investigate patients suffering from recurrent candidosis to establish whether these women develop symptoms or signs at lower yeast counts than other women.

We thank the staff of the genitourinary medicine clinic, Bristol Royal Infirmary, and Fishponds and Shirehampton family planning clinics for their help and co-operation.

\section{References}

1 Oriel JD, Partridge BM, Denny MJ, Coleman JC. Genital yeast infections. Br Med J 1972;iv:761-4.

2 Hilton AL, Warnock DW. Vaginal candidiasis and the role of the digestive tract as a source of infection. Br J Obstet Gynaecol 1975;82:922-6.

3 Sautter RL, Brown WJ. Sequential vaginal cultures from normal young women. J Clin Microbiol 1980;11:479-84.

4 Gough PM, Warnock DW, Turner A, Richardson MD, Johnson EM. Candidosis of the genital tract in non-pregnant women. Eur J Obstet Gynecol Reprod Biol 1985;19:237-46.

5 Evans EGV, Lacey CJN, Carney JA. Criteria for the diagnosis of vaginal candidosis: evaluation of a new latex agglutination test. Eur J Obstet Gynecol Reprod Biol 1986;22:365-71.

6 Rajakumar R, Lacey CJN, Evans EGV, Carney JA. Use of slide latex agglutination test for rapid diagnosis of vaginal candidosis. Genitourin Med 1987;63:192-5.

7 Davidson F, Mould RF. Recurrent genital candidosis in women and the effect of intermittent prophylactic treatment. British Journal of Venereal Diseases 1978;54:176-83.

8 Sobel J. Management of recurrent vulvovaginal candidiasis with intermittent ketoconazole prophylaxis. Obstet Gynecol 1985;65:435-40.

9 Sobel J. Recurrent vulvovaginal candidiasis. A prospective study of the efficacy of maintenance ketoconazole therapy. $N$ Engl $J$ Med 1986;315:1455-8. 